\title{
Determination of optimal flotation conditions of low-grade graphite ore
}

\author{
Özcan Öney ${ }^{1, a}$, and Selçuk Samanli ${ }^{1}$ \\ ${ }^{1}$ Usak University, Department of Mining Engineering, 64200 Usak, Turkey
}

\begin{abstract}
In this study, the enrichment of the Kütahya Altıntas graphite ore by flotation was carried out. Flotation parameters such as particle size, $\mathrm{pH}$, type and dosage of collector, and frother dosage, dosage of depressant, as well as solid ratio were investigated. As a result, a clean graphite concentrate of $77.80 \%$ total carbon content was obtained with $46.68 \%$ total carbon recovery.
\end{abstract}

\section{Introduction}

Graphite is a crystalline, polymorphic form of elementary carbon [1]. Graphite is lustrous black carbon mineral which is relatively soft and greasy with a hardness of $0.5-1.0$ on Moh's scale [2, 3]. Depending upon the mode of occurrence and origin, graphite is graded in to three forms: flake-found in metamorphosed rocks as vein deposit, crystalline (lumpy)-found as fissure filled veins, crypto crystalline (amorphous) form in metamorphosed coal beds $[4,5]$. Graphite generally occurs as a result of metamorphism of organic matter in sediments. Flake graphite is assumed to be derived from finegrained sediments rich in the organic matter. As metamorphic grade increases, carbonaceous material converts to amorphous graphite [3,6]. Flake graphite is classified based on the size of the crystal flakes and graded according to their graphitic carbon content and particle size. Microcrystalline graphite is commercially called amorphous graphite [6].

Graphite, due to its various physical and chemical characteristics, has a unique role in different industries [7]. Graphite is used mainly for foundry facings, refractories, lubricants, pencils, batteries, brake linings, bearings, conductive coatings and crucibles $[8,9]$. The specific properties of graphite result in its increasing importance in the refractory industry $[1,10]$.

\section{Background}

To obtain good quality of graphite concentrate, beneficiation is essential in order to obtain optimal prices for the finished product. Froth flotation is commonly used for the concentration of low grade graphite ore [7]. Graphite can be easily enriched by flotation because of its high natural hydrophobicity $[8,11,12,13]$.

\footnotetext{
${ }^{a}$ Corresponding author: ozcan.oney@usak.edu.tr
} 
In graphite flotation, hydrocarbons like kerosene, fuel oil, paraffin and diesel oil or ionic collectors like potassium amyl xanthate, dithiophosphate are generally used as collectors. Pine oil and methyl isobutyl carbinol are used as frothers and sodium silicate, quebracho and starch are used to depress gangue minerals. Optimum $\mathrm{pH}$ in graphite flotation is between 8 and $9[8,11]$. The polyethylene oxide type frothers such as polyoxyproplene glycol butyl ether were also studied as a replacement for MIBC in graphite flotation $[6,14]$. Flotation is carried out in different stages ranging from two to several, depending on the liberation characteristics of the ore to be treated [2].

\section{Materials and methods}

\subsection{Material}

Low grade run-of-mine graphite ore was received from the Kütahya Altıntaş area in Turkey. The ore was crushed in stages and mixed thoroughly. The graphite ore was subjected to $\mathrm{x}$-ray diffraction studies for the mineralogical phase analysis to identify non-graphite minerals. The diffractogram is shown in Fig. 1.

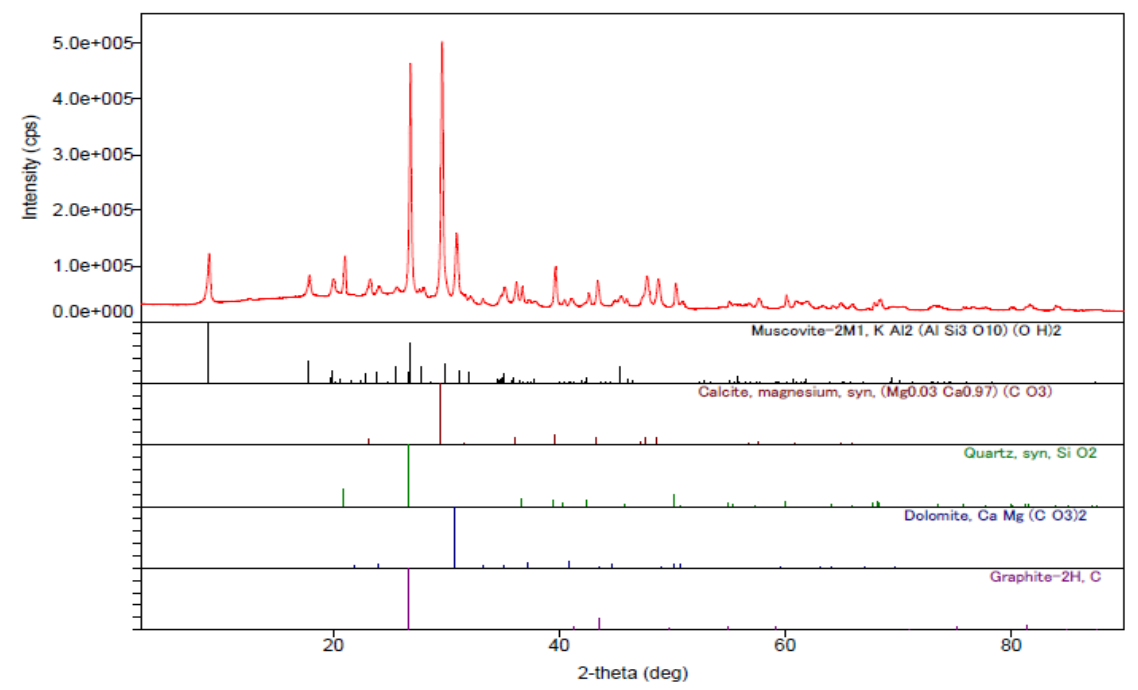

Figure 1. X-ray diffractogram of graphite ore.

The qualitative mineralogical analysis shows that raw graphite consist of muscovite $\left[\mathrm{KAl}_{2}\right.$ $\left(\mathrm{AlSi}_{3} \mathrm{O}_{10}(\mathrm{OH})_{2}\right]$, magnesium calcite $\left[\left(\mathrm{Mg}_{0.03} \mathrm{Ca}_{0.97}\right)\left(\mathrm{CO}_{3}\right)\right]$, quartz $\left[\mathrm{SiO}_{2}\right]$, dolomite $\left[\mathrm{CaMg}\left(\mathrm{CO}_{3}\right)_{2}\right]$ and graphite. According to the results, raw graphite contains $17.56 \%$ of total carbon.

\subsection{Flotation methodology}

The aim of the experiments was to obtain high carbon content of froth products. Firstly, various experiments were performed to determine the most proper rougher flotation conditions. The examined parameters for rougher flotation stage were as follows: optimal particle size, effect of $\mathrm{pH}$, collector type, frother type, solid-liquid ratio and effect of depressant. Then, cleaning and scavenging tests were carried out.

The reagents used in the experiments were collectors, frothers, depressants. Collectors used in the experiments were diesel oil, kerosene and n-dodecane. 4 metyl-2 pentanol, 2ethyl-1 hexanol, tri 
(propylene glycol) butyl ether and pine oil were used as frothers and sodium silicate was used as a depressant.

\subsection{Experimental methods}

Flotation experiments were carried out in a $1 \mathrm{dm}^{3}$ Denver laboratory type flotation machine. In the flotation tests, the impeller speed of flotation machine was kept constant at $1400 \mathrm{rpm}$ for both conditioning and flotation. The tests were done gradually as rough and single cleanings. The pulp was mixed for three minutes prior to addition of collector and after an additional mixing of three minutes, the frother was added. Following a three-minute mixing period, air was introduced into the cell and the froth products were collected for five minutes.

\section{Materials and methods}

\subsection{Optimal flotation parameters for rougher concentrate}

\subsubsection{Effect of optimum particle size fraction}

For examining the effect of size fraction for flotation and to determine the optimum size range, the flotation experiments were carried out for the size fractions of $-0.300,-0.212,-0.150$ and -0.106 . The highest total carbon content and total carbon recovery of the concentrate was obtained for $-0.106 \mathrm{~mm}$ sample as $60.52 \%$ and $54.80 \%$ respectively (Fig. 2).

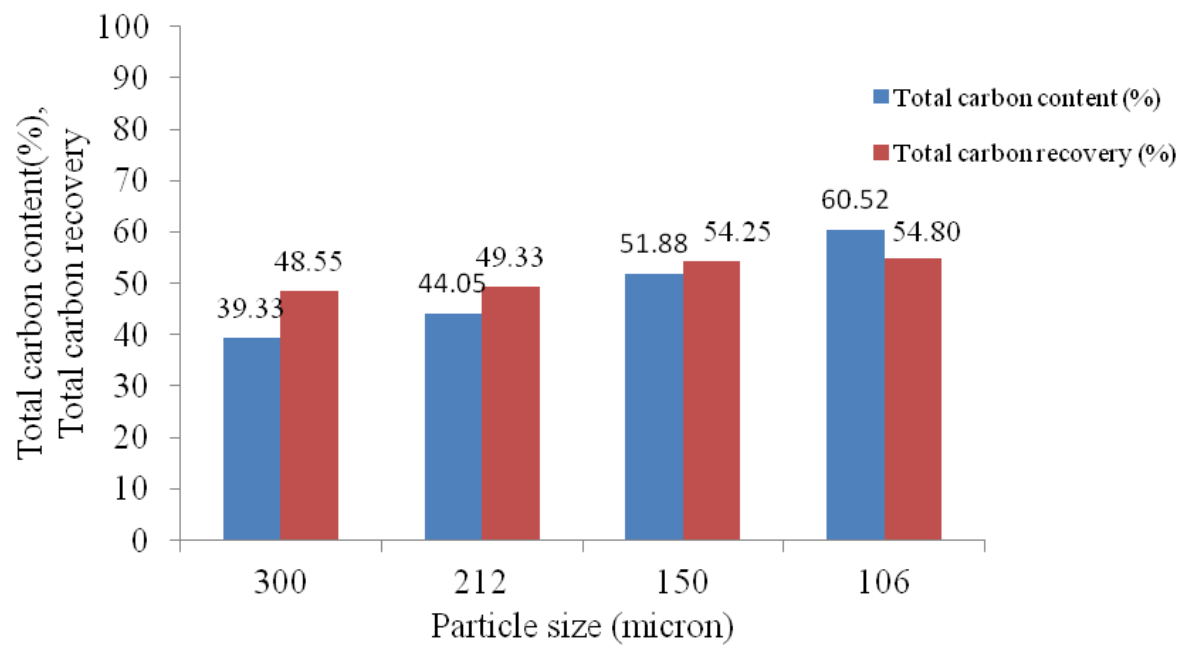

Figure 2. Effect of particle size (diesel oil: $600 \mathrm{~g} / \mathrm{t}$, MBIC: $125 \mathrm{~g} / \mathrm{t}$, solid ratio: $10 \%$ ).

As a result the $0.106 \mathrm{~mm}$ size fraction was used for further experiment steps. The particle size distribution of the crushed and ground graphite ore is shown in Fig. 3. The calculated $d_{80}$ of this graphite sample was found to be $78 \mu \mathrm{m}$. 


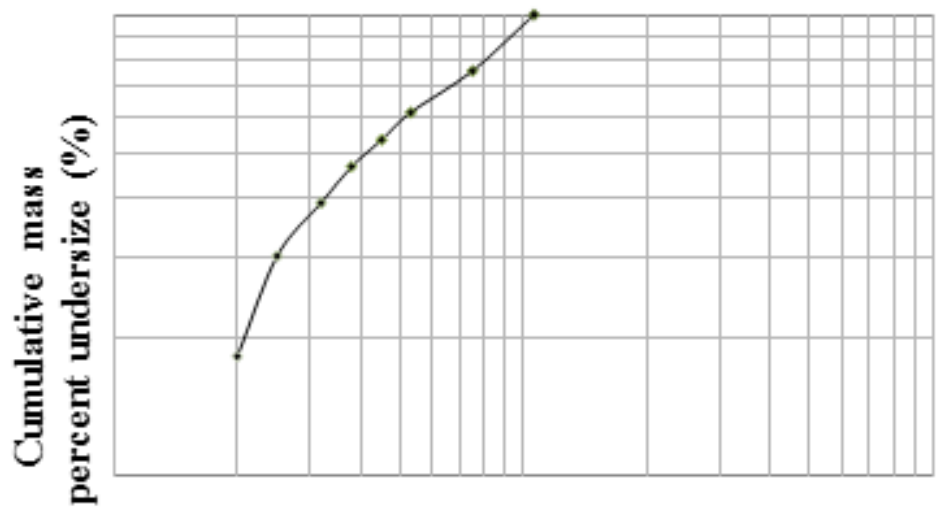

Particle size $(\mu \mathrm{m})$

Figure 3. Particle size distribution of graphite sample $\left(d_{80}=78 \mu \mathrm{m}\right)$.

\subsubsection{Effect of $\mathrm{pH}$}

The flotation trials were conducted at neutral and alkaline $(8-11) \mathrm{pH}$ ranges. $\mathrm{Na}_{2} \mathrm{CO}_{3}$ was used to adjust the $\mathrm{pH}$. The results are shown in Fig. 4. It is clear from Fig. 4 that, while the total carbon content was increasing slightly, the recovery of rougher graphite concentrate showed decreasing trend from $\mathrm{pH}$ value of 8 to 11 . Hence, the further test were conducted at the natural $\mathrm{pH}$ value was equal to 8 .

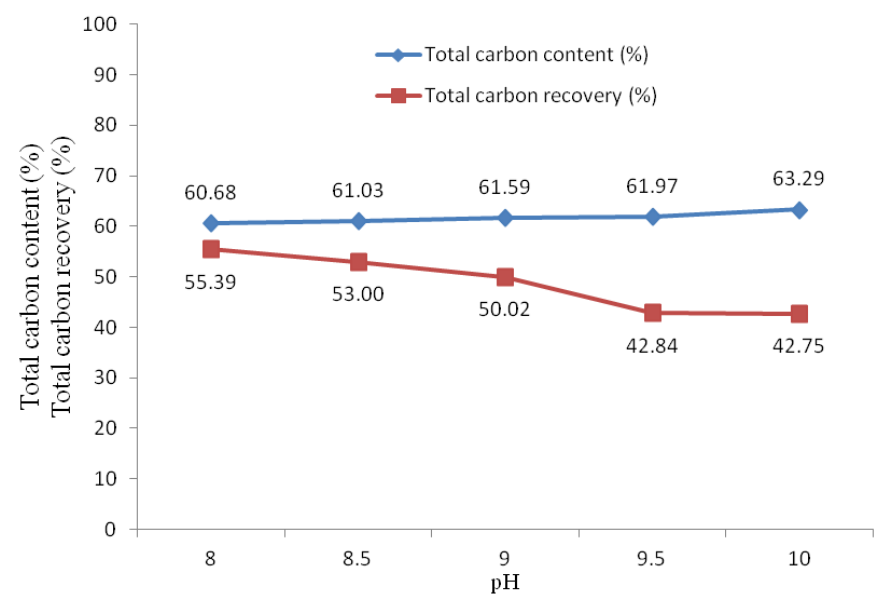

Figure 4. Effect of pH (diesel oil $600 \mathrm{~g} / \mathrm{t}$, MBIC: $125 \mathrm{~g} / \mathrm{t}$, solid ratio $10 \%$ ).

\subsubsection{Effect of depressant dosage}

To determine the effect of depressant dosage, several flotation tests were performed with different dosages of sodium silicate varying from $500 \mathrm{~g} / \mathrm{t}$ to $2500 \mathrm{~g} / \mathrm{t}$. The results obtained are shown in Fig. 5 . With increased depressant dosage, the total carbon content remained constant or slightly increased. Total carbon recovery also remained constant or slightly decreased. It was decided to use sodium silicate at $1000 \mathrm{~g} / \mathrm{t}$ dosage. After this dosage, there was no significant change for total carbon content and the total carbon recovery of the rougher concentrate. 


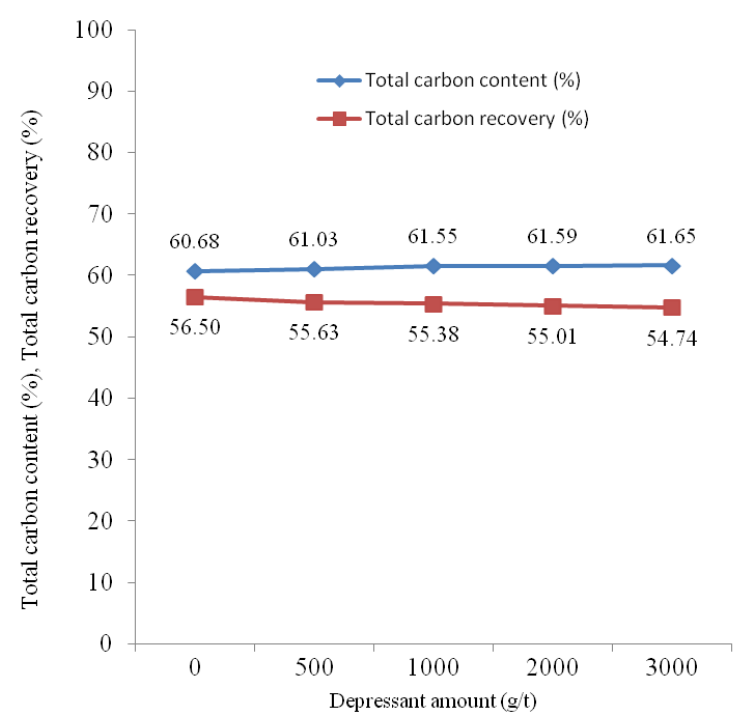

Figure 5. Effect of depressant dosage (diesel oil $600 \mathrm{~g} / \mathrm{t}, \mathrm{MBIC}: 125 \mathrm{~g} / \mathrm{t}$, solid ratio 10\%, $\mathrm{Na}_{2} \mathrm{SiO} 31000 \mathrm{~g} / \mathrm{t}$ ).

\subsubsection{Effect of frother type and dosage}

Initially, a few flotation tests were conducted to study the effect of frother type and dosage on the rougher graphite concentrate. Four different types of frother were used in the experiments. The results shown in Fig. 6.

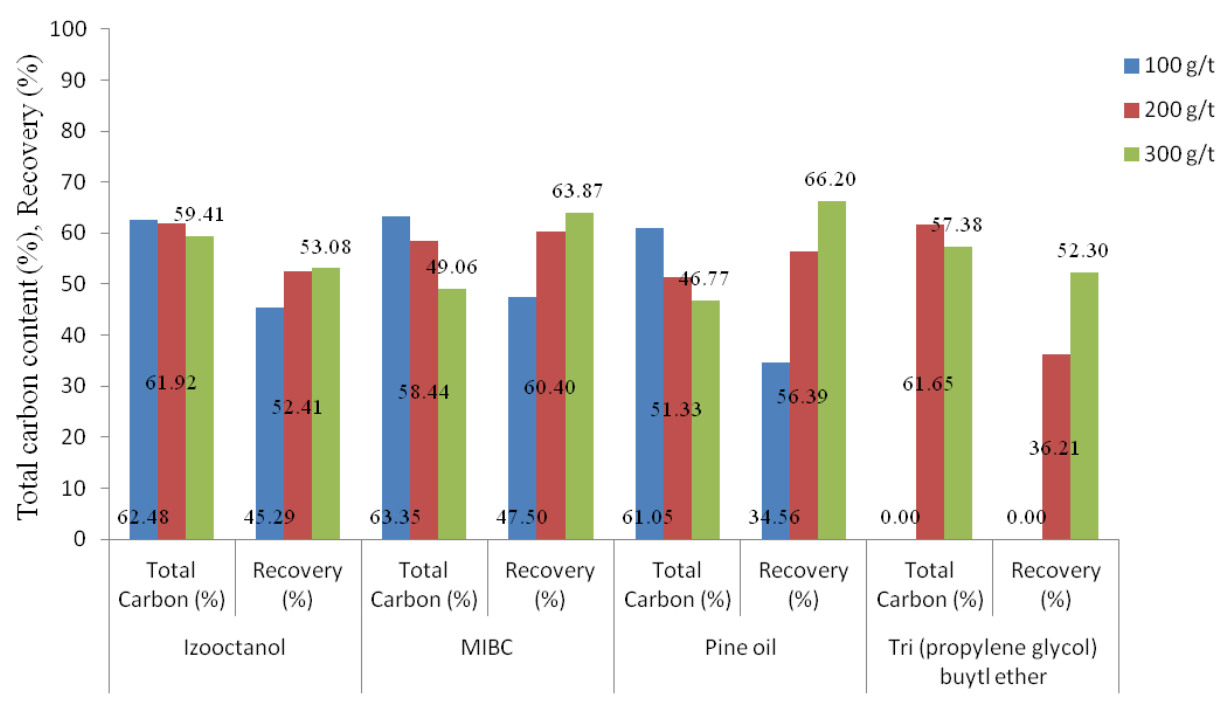

Figure 6. Effect of frother type (diesel oil $600 \mathrm{~g} / \mathrm{t}$, solid ratio 10\%, pH natural (8), $\mathrm{Na}_{2} \mathrm{SiO}_{3} 1000 \mathrm{~g} / \mathrm{t}$ ).

The total carbon content of the rougher concentrate decreased continuously with increasing of frother dosage. It was observed that MIBC was the most effective frother. Hence, the next set of trials were performed using various dosages of MIBC (Fig. 7). 
Taking into account the both total carbon content and total carbon recovery of the rougher concentrate, the proper dosage of MIBC was $175 \mathrm{~g} /$ ton.

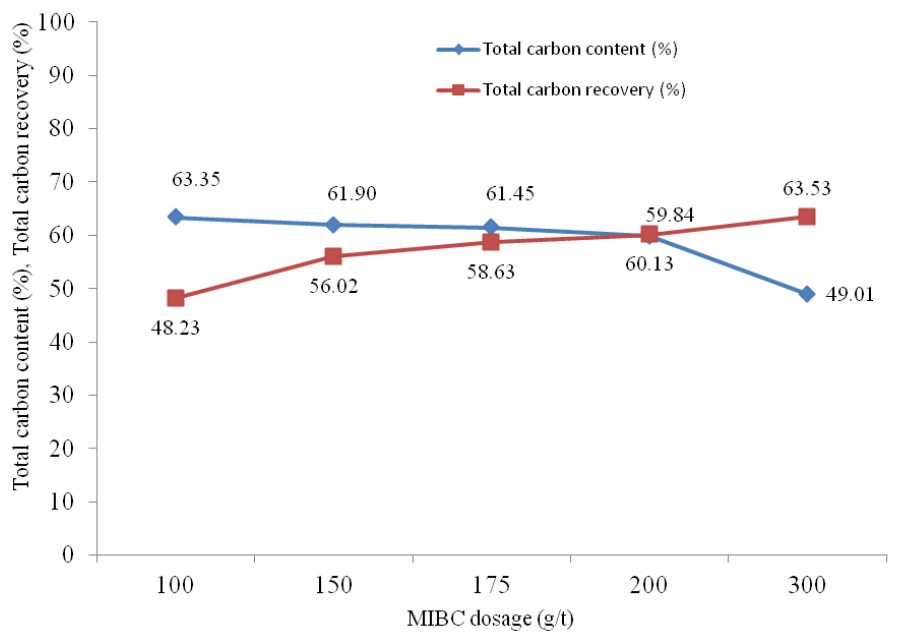

Figure 7. Effect of MIBC dosage (diesel oil $600 \mathrm{~g} / \mathrm{t}$, solid ratio $10 \%, \mathrm{pH}=8, \mathrm{Na}_{2} \mathrm{SiO}_{3} 1000 \mathrm{~g} / \mathrm{t}$ ).

\subsubsection{Effect of collector type and dosage}

To determine the effect of collector type and dosage on graphite flotation, diesel oil, kerosene and ndodecane were tested. The results are shown in Fig. 8.

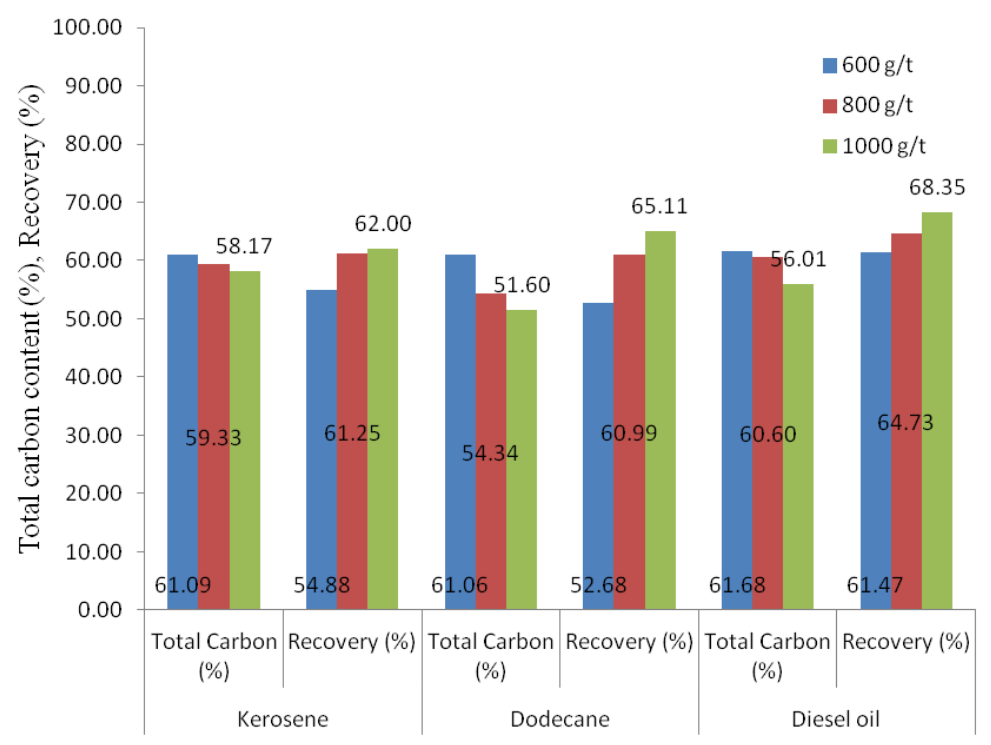

Figure 8. Effect of collector type (type (frother $175 \mathrm{~g} / \mathrm{t}$, solid ratio $10 \%, \mathrm{pH}=8, \mathrm{Na}_{2} \mathrm{SiO}_{3} 1000 \mathrm{~g} / \mathrm{t}$ ).

In terms of the total carbon content and total carbon recovery of the rougher concentrate, the best results were obtained with diesel oil. At the dosage of $600 \mathrm{~g} / \mathrm{t}$ diesel oil, the rougher concentrate with $61.68 \%$ total carbon content was obtained with $60.47 \%$ total carbon recovery. Diesel oil was selected 
as the collector for determining the other steps and the optimal dosage of $800 \mathrm{~g} / \mathrm{t}$ diesel oil was thought to be appropriate.

\subsubsection{Effect of solid ratio}

Several experiments were performed to determine the optimal solid rate (Fig. 9.). The total carbon content of $60.60 \%$ was obtained with the total carbon recovery of $64.73 \%$ at solid ratio of $8 \%$. It can be seen that the solid ratio was determined as $12 \%$ (Fig. 9).

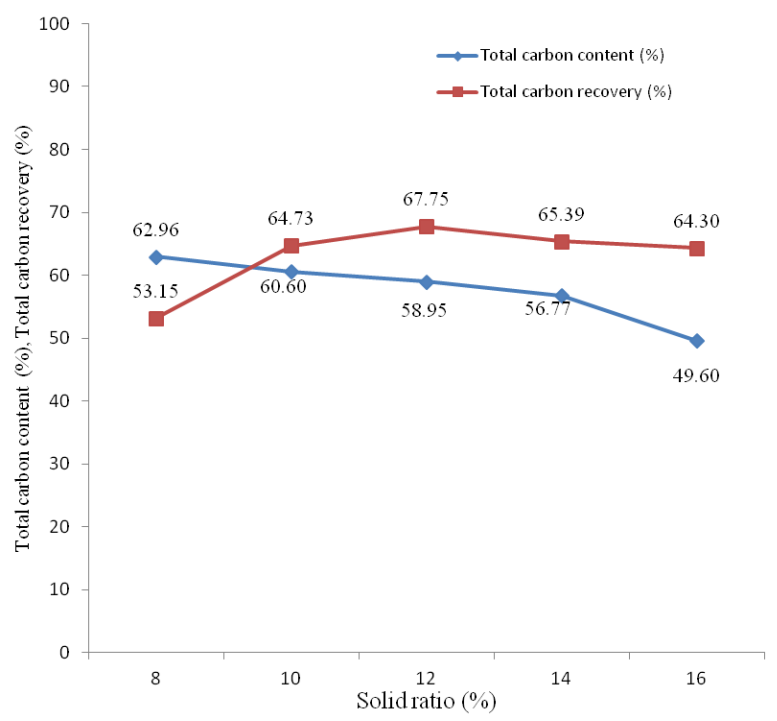

Figure 9. Effect of solid-liquid ratio ((MIBC $175 \mathrm{~g} / \mathrm{t}$, diesel oil $800 \mathrm{~g} / \mathrm{t}$, solid ratio $10 \%, \mathrm{pH}=8, \mathrm{Na}_{2} \mathrm{SiO}_{3}$ $1000 \mathrm{~g} / \mathrm{t})$.

\subsection{Improvement in concentrate grade by cleaning flotation}

The flotation tests were carried out using optimum flotation reagents and conditions for rougher flotation followed by cleaner and scavenger flotation. A schematic flowsheet of graphite flotation is shown in Fig. 11. Reagent types and their dosage for each flotation stage are also illustrated in Fig. 10. The graphite concentrate containing $77.80 \%$ total carbon can be obtained with the recovery of $46.68 \%$.

\section{Conclusions}

The optimum particle size was determined as $0.106 \mathrm{~mm}$. While the total carbon content increased slightly, the recovery of rougher graphite concentrate showed a decreasing trend from $\mathrm{pH} 8$ to 11 . Hence, the natural $\mathrm{pH} 8$ was kept fixed in the tests. Kerosene, n-dodecane and diesel oil were tested as collectors and among them diesel oil was found to be the most effective. Four different types of frother were examined and the best results were obtained with MIBC. The dosage of sodium silicate had a small influence on the total carbon content and the total carbon recovery of the rougher graphite concentrate.

It was found that rougher, cleaner and scavenger flotation stages should be applied to obtain the high content and recovery of carbon. A clean graphite concentrate of $77.80 \%$ total carbon content was obtained with $46.68 \%$ total carbon recovery. 


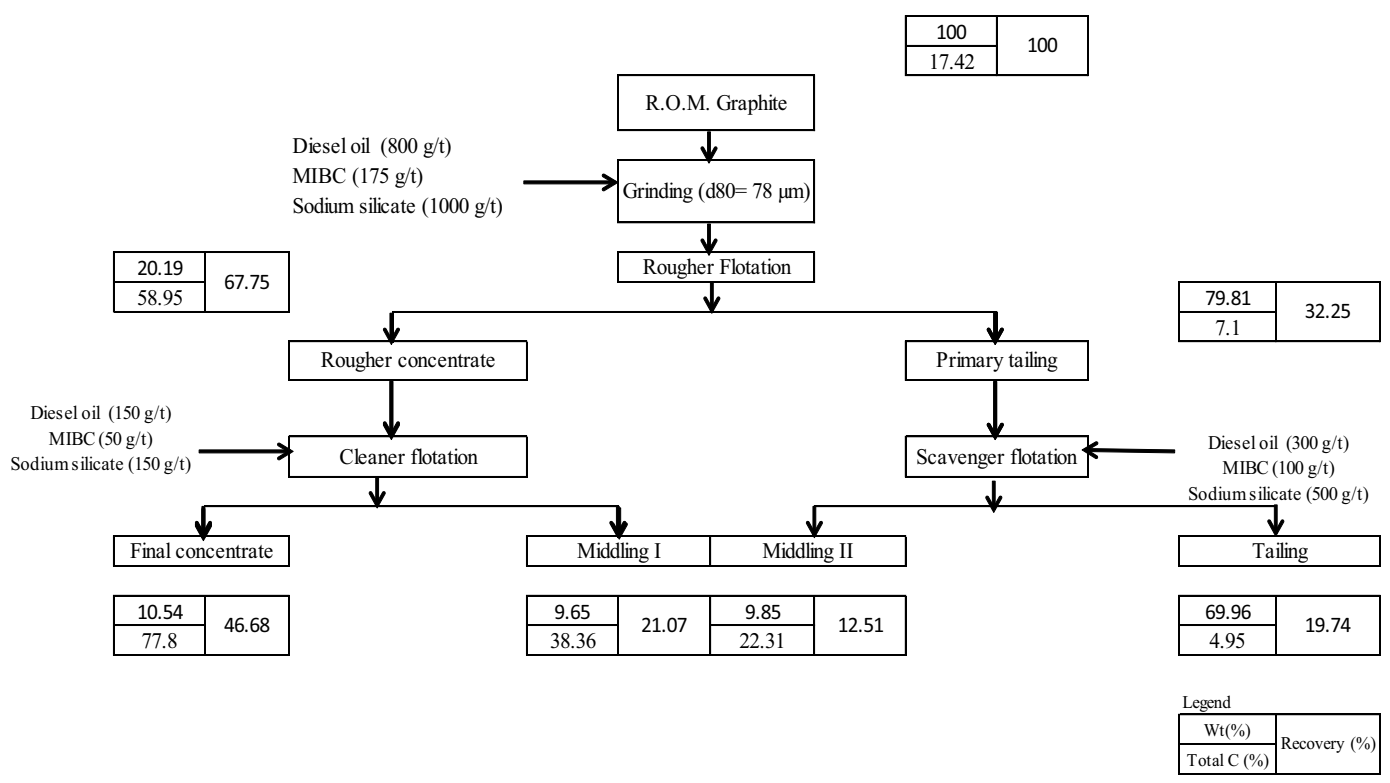

Figure 10. Schematic flowsheet of graphite flotation.

\section{Acknowledgement}

This work was supported by Research Fund of Usak University, Usak/Turkey. Project Number: 2014/MF015.

\section{References}

1. B. Kwiecinska, H.I. Petersen, Int. J. Coal Geol., 57, 99 (2004)

2. N. Vasumathi, T. Vijaya Kumar, V. Nayak., S. Subba Rao, S. Prabhakar, G. Bhaskar Raju, J. Min. Metall., 1, 9 (2014)

3. C.J. Mitchell, British Geological Survey Report No. WG/92/30 (1993)

4. S.K. Nuhu, , C. J. Appl. Sci., 9(2), 31 (2014)

5. M.S. Klima, F.F. Aplan, P.T. Luckie, Elements of Mineral Processing: Lecture Notes (The Pennsylvania State University, 2010)

6. N. Vasumathi, T.V. Vijaya Kumar, S. Ratchambigal, S. Subba Rao, S. Prabhakar, G. Bhaskar Raju, B.R. Nayak, S. Shiva Kumar, U. Raman, in Proceedings of the XIII International Seminar on Mineral Processing Technology,145 (2013)

7. V. Ravichandran, C. Esweraiah, P. ve Manisankar, Ultra Chemistry, 8(2) 159 (2012)

8. O. Kaya, M. Cambazoğlu, The Journal of Ore Dressing, 9, 17 (2007)

9. L.L.Y. Chang, Industrial Mineralogy Materials, Processes and Uses (Prentice-Hall Inc., 2002)

10. K. Galos, P. Wyszomirski, Ceram.-Pol. Ceram. Bull. 64, 59 (2001)

11. N. Arbiter, Flotation, SME Mineral Processing Handbook (Soc. of Mining Engineers, New York, 1985)

12. P. Crossley, Ind. Miner.,March, 31 (2000)

13. B.C. Acharya, D.S. Rao, S. Prakash, P.S.R. .Reddy, S.K. Biswal, Min.Eng., 9, 11 (1996)

14. R.J. Pugh, Miner. Eng., 13, 2, 151 (2000) 